\title{
A CAPOEIRA NO RIO DE JANEIRO: uma investigação do universo simbólico no discurso dos mestres
}

\author{
Jorge Felipe Columá \\ Simone Freitas Chaves ${ }^{2}$ \\ Felipe da Silva Triani ${ }^{3}$
}

\section{RESUMO}

O artigo busca visitar o universo da capoeira e suas relações com aspectos simbólicos que, ao longo dos tempos, ajudaram a construir osdiscursos dos capoeiristas da cidade do Rio de Janeiro, a fim de desvelar algumas possíveis tramas simbólicas. Para atingir o objetivo, foram realizadas entrevistas com mestres de capoeira com mais de 30 anos de mestrado. Os resultados possibilitam perceber que o berimbau aparece como catalisador do universo simbólico dos capoeiristas. Portanto, perpassa seus símbolos, mitos e sua religiosidade.

Palavras-chave: Práticas corporais. Berimbau. Ritual. Universo simbólico

1 Pós-Doutor em Artes. Professor do Centro Universitário Augusto Motta (UNISUAM). Rio de Janeiro/Rio de Janeiro, Brasil. E-mail: jorgecoluma@gmail.com

2 Doutora em Educação Física. Professora da Escola de Educação Física e Desportos da Universidade Federal do Rio de Janeiro (EEFD-UFRJ). Rio de Janeiro/Rio de Janeiro, Brasil. E-mail: chavessimone@terra.com.br

3 Mestre em Humanidades, Culturas e Artes. Professor da Faculdade Gama e Souza. Rio de Janeiro/Rio de Janeiro, Brasil. E-mail: felipetriani@gmail.com 


\section{CAPOEIRA IN RIO DE JANEIRO: a universe of research in symbolic speech of masters}

\section{ABSTRACT}

The article seeks to visit the world of capoeira and its relations with symbolic aspects that, over time, helped build the speeches of the capoeiristas of the city of Rio de Janeiro in order to reveal some possible symbolic plots. To achieve the goal, interviews were conductedwith capoeira masters with over 30 years of Masters was held. The results make it possible to realize that the berimbau appears as a catalyst for the capoeiristas symbolic universe. So runs through its symbols, myths and their religion.

Keywords: Body practices. Berimbau. Ritual. Symbolic universe

\section{LA CAPOEIRA EN RÍO DE JANEIRO: un universo de la investigación en discurso simbólico de masters}

\section{RESUMEN}

El artículo trata de visitar el mundo de la capoeira y sus relaciones conlos aspectos simbólicos que, coneltiempo, ayudaron a construir los discursos de los capoeiristas de laciudad de Río de Janeiro conelfin de revelar algunosposibles tramas simbólicas. Para lograr el objetivo, se llevó a cabo entrevistas conlos maestros de capoeira con más de 30 años de Maestros. Los resultados permitendarsecuenta de que el berimbau aparece como un catalizador para los capoeiristas universo simbólico. Así que corre a través de sus símbolos, mitos y sureligión.

Palabras clave: Prácticas corporales. Berimbau. Ritual. Universo simbólico 


\section{INTRODUÇÃO}

A trajetória da capoeira perpassa por momentos perigosos de crimes e conflitos, assim como outros de ludicidade, festejos, nos jogos e no samba, como nos mostra seu legado (MOREIRA, 2007). Na trilha deste universo sinuoso permeado de ginga e malandragem, buscamos identificar algumas marcas discursivas concernentes ao imaginário simbólico que compõe a roda de capoeira.

Em se tratando da capoeira, a literatura oferece deleitosa contribuição acerca de sua emergência por meio de algumas hipóteses, sendo uma delas conhecida como urbana, que aponta sua origem nas praças do mercado de aves, na cidade do Rio de Janeiro (DE LOS RIOS, 2000; SOARES, 1994), outra intitulada de rural, aduzindo que a capoeira era praticada nos matos baixos, nomeados na língua Tupi-Guarani de Caapuera, chamados de capoeira (MOREIRA, 2011) e ainda, uma que indica a capoeira como de origem africana, oriunda de um ritual chamado N'golo, em que os jovens guerreiros de uma etnia africana (Mucopi), disputariam as jovens que obtinham sua primeira menarca (BOLA SETE, 1997).

É possível perceber uma síntese de múltiplas determinações sobre a capoeira. Contudo, o que se passa no imaginário cantado nas rodas de capoeira? Quais são os efeitos da convergência entre corpo, movimento, berimbau, atabaque, pandeiro e cânticos sobre a constelação de símbolos que compõem o universo imaginário do capoeirista? Essas e outras questões norteadoras são discutidas nas marcas discursivas de mestre de capoeira com mais de 30 anos de mestrado, a fim de compreender indícios dos processos de significação inscritos nos discursos, seguindo essas pistas, buscamos ainda explicitar os sentidos produzidos pelos mestres de capoeira capoeiristas em sua relação com a exterioridade e com as condições em que estes são produzidos. Com efeito, revelando crenças, ideologias, desejos, fantasias, enfim traços dos imaginários sociais dos capoeiristas.

Diante dessa construção epistemológica acerca do imaginário social (MAFFESOLI, 2005) do capoeirista, procuramos revisitar o universo da capoeira e suas relações com aspectos simbólicos que, ao longo dos tempos, ajudaram a construir o imaginário social dos capoeiristas do Rio de Janeiro. A fim de desvelar esse imaginário e suas tramas simbólicas, nos propusemos a apreender alguns sentidos circulantes, presentes nos discursos dos mestres de capoeira entrevistados.

\section{METODOLOGIA: ENTRANDO NA RODA}

Adotamos uma pesquisa do tipo qualitativa, pois possibilita a utilização de entrevistas e sua análise. Dessa maneira, entrevistas foram utilizadas como instrumento de coleta de dados para capturar os discursos de 11 mestres de capoeira com no mínimo 30 anos de mestrado na modalidade, todos atuantes na cidade do Rio de Janeiro.Cabe ressaltar que todos os mestres se intitularam ser da "capoeira carioca", dispensando qualquer vínculo à capoeira regional ou angola. 
As entrevistas foram realizadas individualmente e durante o roteiro, convidamos os sujeitos a se transportarem, a falar de suas percepções ao ouvir o som do berimbau, atabaque, do pandeiro e dos cânticos. A leitura dos dados foi desenvolvida sob a luz da Análise do Discurso na perspectiva de EnyPuccineliOrlandi (2001). Nesse sentido, de acordo com a autora, tal análise não trata da língua nem da gramática, mas sim do discurso, que é a palavra em movimento. Na análise buscamos a compreensão dos sentidos presentes nos diferentes discursos e não a interpretação de texto como se propõe na linguística tradicional, procurando compreender a língua fazendo sentido, enquanto elemento simbólico e constitutivo do capoeirista e da sua história.

Cabe ressaltar que todos os participantes assinaram um termo de consentimento livre e esclarecido, autorizando sua participação, e que a pesquisa foi aprovada pelo Comitê de Ética em Pesquisa através do CAAE de número 0084.0.312.000-11.

\section{O berimbau}

A guisa de conhecimento para o leitor menos familiarizado com o ritual da capoeira procederemos a uma breve apresentação do instrumento que emergiu com um destacado poder simbólico na fala dos sujeitos.

O berimbau é um instrumento monocórdio oriundo da África e lá é chamado de urucungo utilizado em rituais festivos afro-brasileiros. Em Cuba é conhecido como burumbumba(COLUMÁ; CHAVES, 2013) e segundo Rego (1968) é possuidor de poderes mágicos, utilizados em cerimônias religiosas servindo de elo entre o mundo dos vivos e o mundo dos mortos. Shaffer (1977) categoriza o berimbau como da família dos arcos musicais, classificados por Sachs (1940) mais comumente como harpas. A harpa simboliza a ligação entre a terra e o céu, uma condução para outro universo. Durante a existência terrena ela representa as tensões entre os instintos materiais e as aspirações espirituais figuradas pelas vibrações de suas cordas (CHEVALIER; GHEERBRANT, 2003).

O berimbau é um arco musical que possui uma cabaça, responsável pela ressonância do instrumento. A cabaça aparece em diversas culturas como aglutinadora dos elementos responsáveis pela criação do mundo, às vezes simbolizando o ovo do universo (IBIDEM). Na mitologia Nagô, as cabaças guardavam as sementes da criação da terra e seus habitantes, assim como os apetrechos mágicos do Orixá Exu (OGBEBARA, 1998).

Existem três tipos de berimbau: o primeiro, com o som mais grave, é conhecido como Gungaou berra-boi; o segundo um pouco mais agudo, conhecido como médio; e o terceiro bem agudo conhecido como viola ou violinha(COLUMÁ; CHAVES, 2013). Encontra-se formação semelhante em outras manifestações afro-brasileiras como o candomblé e o jongo, ambos possuidores de três atabaques, cada um com função distinta. No caso do candomblé: Rum, Rumpi e Lê, e no jongo Tambu,Candongueiro e Angoma-puita(CASCUDO, 2001). Não se sabe ao certo quando o berimbau veio a se unir ao ritual da capoeira, mas se sabe que o instrumento era usado pelos negros de ganho, que eram escravos vendedores de rua, a fim de chamar a atenção dos transeuntes para seus produtos (BIANCARDI, 2000). 
Soares (1994) e Pires (2010) defendem a tese de que a sobrevivência da capoeira baiana em muito se deveu à presença do berimbau no ritual. Sua musicalidade conferiu maior atratividade à capoeira, que passou a figurar nas diversas festas de largo em Salvador, vindo a compor o folclore baiano junto com as danças de Orixás e outras manifestações culturais. Para os autores, a capoeira carioca, além de sofrer uma perseguição implacável pelas autoridades policiais, não teve a adesão do berimbau, que agregaria outros sentidos para além da capoeira luta. Na fala dos mestres entrevistados encontramos ecos dessa memória. Vejamos:

Hoje é fácil ouvir esses barulhos, eu me lembro que há algum tempo atrás você quase não ouvia o pandeiro, berimbau, atabaque (Mestre -3 ).

Eles têm que pensar que hoje em dia está fácil jogar capoeira, você tem que respeitar essa arte, como se respeita essa arte? Com disciplina, com educação, mas também na hora de reverência ali, tem que pensar como foi o inicio, como os negros sofreram (Mestre - 8).

No início da capoeiragem ela teve um início nobre, depois teve origem escrava, depois a malandragem tomou isso, tanto que foi reprimida. Foi pela repressão a malandragem, aos navalhistas, e uma séries de coisas (Mestre - 8).

Antes era muito difícil pra jogar capoeira aqui, que a polícia não deixava, antes de 73, que a capoeira estava no código penal, não podia andar, correr, fazer exercícios de agilidade em praça pública, antigamente era proibido (Mestre - 1).

A capoeiragem carioca parece encontrar seus últimos vestígios em Sinhozinho e sua capoeira luta, sem o uso do berimbau, que pode ter entrado na cena da capoeira carioca com os mestres baianos: Artur Emídio, Paraná e Mario da Bonfim, todos radicados entre os bairros de Bonsucesso e Higienópolis, indicando uma possibilidade de fatores culturais, locais, facilitadores para essa confluência. A fala dos sujeitos da pesquisa reforça essa narrativa na medida em que esses mesmos mestres tiveram contato direto com esses precursores, ouçamos:

Olha, quando eu comecei a capoeira, existiam três grupos de capoeira, o grupo são bento pequeno, do saudoso mestre Paraná, o meu mestre, Mario dos santos, que era Mario busca pé da Bonfim e o grupo de capoeira do Arthur Emidio (Mestre -6).

Aqui no Rio de Janeiro existia um Mestre que tocava berimbau que era o Mestre Paraná e ensinou a muita gente, muitos Mestres a tocar berimbau, não sei se você é conhecedor disso, ele era o chefe do ritmo da academia do Artur, tocava com o Mario dos Santos na academia Bonfim, mas tem Mestre que não pega no berimbau, Mestre tem que ser completo (Mestre - 10).

Eu tive a sorte de conviver com esses capoeiristas, que moravam tudo lá naquela área da Leopoldina (Mestre - 10). 
O berimbau aparece como elemento primordial no ritual da capoeira, mobilizador dos sujeitos, continuamente reafirmado como um importante capital simbólico, que era aquilo de valor reconhecido pelo grupo, por conseguinte, fonte de demérito para quem não detém a ciência do seu correto manejo. Ansart (1978) aponta o quanto o desconhecimento dos mecanismos simbólicos denota em desprestígio no grupo e uma ocupação inferior no ritual. Nesta perspectiva, o antropólogo Claude Lévi-Strauss (1989) reforça a valorização simbólica destinada aos detentores dos conhecimentos ritualísticos, pois além de ocupar um lugar de destaque no rito, eles são indispensáveis na medida em que a sua falta ameaça a vitalidade do grupo. Vejamos na capoeira como este capital é legitimado:

Não se deve dar o berimbau para qualquer um, o berimbau maior que é o Berra-boi, que hoje o pessoal chama de Gunga, não dar na mão de alunos, porque ele é o berimbau da orquestra que mantém a cadência do jogo é ele que puxa o toque (Mestre - 2).

O berimbau Gungana roda de capoeira, além de funcionar como balizador do ritmo aplicado ao jogo, serve como um símbolo de poder, pois em posse dele o mestre comanda a roda, escolhendo os participantes e o ritmo para a contenda(COLUMÁ; CHAVES, 2013). O Gungaé tão importante para o ritual da roda, que apenas mestres ou capoeiristas antigos, detentores dos fundamentos devem manuseá-lo, porque, segundo os praticantes é no berimbau Gungaque está o segredo do axé na roda de capoeira (MOREIRA, 2007).

A interdição para a entrega do Gunga na mão de alunos denota uma hierarquia dentro do grupo, cabendo aos mestres e conhecedores do ritual, a posse desse instrumento. A expressão "qualquer um", nos ajuda a compreender o desvalor reservado para quem desconhece os fundamentos, não basta ser mestre, tem que deter os códigos, doar-se ao rito por inteiro, entregar-se.

O mestre de capoeira para mim, ele tem que ser completo, ele tem que tocar atabaque, berimbau, pandeiro e jogar bem (Mestre-11).

O capoeirista ideal é aquele que joga qualquer ritmo, tocar, cantar, que pudesse fazer muitas coisas (Mestre - 4).

Um bom mestre seria se no caso fosse um mestre, seria um bom jogador, bom educador, um tocador, um bom cantador, soubesse falar sobre a capoeira, enfim que ele fosse bom em todas essas vertentes (Mestre - 5).

Um cara que contribua com o todo e que participe de todo ritual de um modo completo, não precisa ser bom em uma só coisa, mas poderia ser bom em muitas outras coisas, esse é o modo ideal ser participativo de um modo geral na roda de capoeira (Mestre - 7).

Não basta deter um tipo de conhecimento na capoeira, é preciso desenvolver diversos aspectos, uma gama de informações que superam os limites físicos do jogo. Esse 
aprendizado necessita grande dedicação devido a capoeira possuir múltiplos aspectos, dentre eles, marcial, lúdico, musical entre outros. , "Como a capoeira é muito rica, fica difícil você ser bom em tudo". A dedicação ao ritual parece abrir as portas para uma entrega, uma devoção. Vejamos algumas passagens que reforçam essa ideia.

Primeiro amar a capoeira abaixo de Deus, amar mesmo não é gostar, amar.

Amo a capoeira porque dela eu fiz o meu ideal e até hoje eu falo, ela é o meu ideal. E eu acho que eu vou morrer capoeirista, então esses mestres que se foram a pouco tempo,acho que todos tinham a mesma ideia que eu tenho, os românticos da capoeira (Mestre - 9).

Eu já falei pra você que eu não vivo de capoeira, eu vivo para capoeira, eu gosto da capoeira, a capoeira vem a ser uma parte enorme da minha vida, comecei na capoeira em 1956, eu estou com 61, veja quantos anos tem, o que ela representa pra mim (Mestre - 9).

A primeira coisa é aquela vontade de ver da onde vem e quem não sente essa vontade não é capoeirista (Mestre - 9).

Capoeira pra mim é a vida é uma filosofia de vida.A capoeira é a minha filosofia de vida.Eu não abandono ela pra nada (Mestre - 9).

O coração acelera, eu tenho que ir lá ver o que é? O que não é? Quem é? Eu acho que um capoeirista que não se arrepia ao escutar o som do pandeiro, das palmas do canto, não tem alma (Mestre - 9).

Para Lévi-Strauss (1989) o rito é capaz de alimentar o sentimento vital, a alma do praticante. Os cânticos, os ritmos, os mitos invocados, possuem o papel de harmonizar os sujeitos dando sentidos as suas práticas, assim como coesão ao grupo. No mesmo sentido, Ansart (1978) nos mostra como o conhecimento mítico distingue os sujeitos, cabendo aos detentores desses conhecimentos transmiti-los aos demais membros. Na esteira dos autores vale refletirmos acerca da capoeira e seus saberes, conhecidos também como fundamentos, em que cabem aos mais antigos, os mestres, passarem esses ensinamentos aos mais novos, a fim de manter a harmonia do ritual e o sentido de pertencimento ao grupo. Durante a roda é comum os mestres perpetuarem esses fundamentos, através dos toques, dos cantos, do corpo, das metáforas, enfim, do rito. Um convite a essa experiência:

Existe o ritual, você chama o individuo para o pé do berimbau e faz ele sentir no corpo e na alma, aquilo que está tocando e cantando (Mestre - 7).

É a experiência que ele aprende com os mestres mais velhos e daí aprende aquilo ali como tônico (Mestre - 7). 
Você ouve os mais velhos cantar, o mestre fala meu filho, vosmicê espere um pouco, e já começa a aprender (Mestre - 7).

O ritual, aquele que acontece, aquilo que você sente, acontece mesmo no jogo da capoeira, entendeu? (Mestre - 11).

O ritual, a magia, aquela coisa maravilhosa que é a capoeira (Mestre - 11).

A fala aponta para expressões que parecem vitalizar os sentimentos dos capoeiristas, que, como numa possessão, são tomados pelo ritual da capoeira, desviando-se do aspecto racional para seguir a "magia" do berimbau. Uma espécie de transe que nasce com o ritmo, os toques, os cânticos, os gestos, os símbolos, confluindo em uma espécie de onda que invade os sujeitos, deslocando-os para outra realidade, a realidade da roda, do rito.

\section{O Ritual}

Lévi-Strauss (1989) nos apresenta o universo mágico dentro dos rituais xamanísticos, bastante significativo para os sujeitos integrados no rito. $\mathrm{O}$ autor discorre sobre as práticas ritualísticas e seus elementos, como cânticos e demais apetrechos, que investidos de poder simbólico, são eficazes dentro do ritual. Neste sentido, torna-se inequívoca uma alusão ao berimbau como elemento simbólico capaz de reunir esse poder aglutinador dentro do rito da capoeira e assim travar um tecido denso com os capoeiristas.

O toque do berimbau, ele tem uma energia positiva e ele pode te atrair...

A gente se atrai, assim que o berimbau the atrai e fica perto parece que ele esta lá embaixo e de repente está ao seu lado (Mestre -6).

O capoeirista que é capoeira mesmo, quando escuta vai lá, chega perto, fica com vontade de se envolver e participar (Mestre - 6).

Rapaz! É uma euforia que parece que sai um gol do seu time, você não sabe se você pula ou se você fica quieto, pra você não dar uma de maluco no meio da rua você é envolvido pela capoeira (Mestre - 9).

É coisa que está no sangue, é como se fosse um chamado, escutei o berimbau chamar eu vou atrás, faz parte íntima da minha vida (Mestre - 9).

É difícil de explicar, é como a comida, é necessário como a comida, como a água, como a companhia dos meus amigos, a capoeira me faz viver pra vida (Mestre - 9).

Podemos conceber essa musicalidade como um passaporte para outro lugar, pois além do berimbau como elo, encontramos na simbologia do tambor (atabaque), também 
um significado de transporte do mundo do visível para o mundo do invisível (CHEVALIER; GHEERBRANT, 2003). Destarte, o ritmo comandado pelo berimbau e marcado pelo atabaque pode realizar a mediação entre o Orun (céu) e o Aiê (terra), um portal que conduz o capoeirista ao sagrado, à Aruanda, o paraíso na cultura Nagô (MOREIRA, 2007).

As falas remetem a umarrebatamento do capoeirista que ao ouvir o toque do berimbau não hesita em seguir a melodia. Ela aparece como um fio condutor que liga o capoeirista à roda tornando irresistível o seu "chamado", sendo atraído, da mesma forma como eram os marinheiros ao ouvir o canto da sereia em alto mar. O magnetismo que o berimbau exerce sobre os capoeiristas da pesquisa nos remete a um arroubo emocional incontrolável, uma adesão voluntariosa capitaneada através de seu som dolente. Podemos utilizar também como metáfora o conto dos irmãos Grimm (2002) "o flautista de Hamelin", que através de sua flauta hipnotizava quem ouvisse a melodia entoada. Senão vejamos:

Já aconteceu comigo, eu estava num ônibus e vi uma roda de capoeira eu desci do ônibus e fui jogar capoeira (Mestre - 9).

Ouvi o berimbau tocar, não pude me controlar, olha, eu corri logo para ir lá pra ver (Mestre - 9).

Uma coisa que pode me desviar de qualquer outra coisa é o som do berimbau (Mestre - 2).

Primeiramente eu me imagino dentro da roda, é difícil o capoeirista passar e ouvir o som do berimbau e não parar (Mestre - 2).

Eu sinto a vibração, sinto a vontade de chegar perto, e se não der vontade de jogar também, vontade de participar do ritual (Mestre -6).

Na fala dos sujeitos, o ritual da capoeira não aparece reduzido à prática do jogo, transcende-o em muito. O ritual começa muitas vezes bem antes da roda, até mesmo na confecção do berimbau, "você pra cortar uma verga na mata você sabe que tem que pedir licença, você tem quem saber o que precisa pra cortar a madeira na mata, cortar, quebrar, essa coisa bonita que é a natureza". Existe uma preparação que vai da confecção e afinação dos instrumentos à sacralização do local, conforme ensina Mestre João Grande no documentário Mandinga em Manhattan (2006).

Tocar berimbau ou qualquer outro instrumento, bater palmas, entoar os cânticos, sentir o axé, são elementos vitais para a manutenção do rito. É certo que cada estilo de capoeira possui seus próprios fundamentos, assim como cada mestre direciona o ritual de sua roda, mas parecem existir premissas básicas, comuns aos capoeiristas entrevistados, como o canto, os instrumentos, os gestos e a roda.

Então, é cada um pode fazer um tipo de roda, mas o ritual tem que permanecer, e o quê seria? Respeitar os colegas, ir ao pé do berimbau, antes de sair do jogo, 
cumprimentar o colega, obedecer ao ritmo que está tocando, se tá tocando angola eu não posso ficar agarrando o colega. Se for o toque de iúnaeu tenho que estar preparado pra aquele tipo de jogo, se tiver tocando São Bento Grande de Angola, pode permitir que o cara faça acrobacias (Mestre -6).

Para respeitar o ritual ele tem que saber jogar, fazer o jogo duro, e as acrobacias dele, dentro do jogo duro, ele vai ter que fazer isso, ou então ele vai ter que ficar brigando, chutando um ao outro, e já sai completamente, porque a hora de luta é outra coisa (Mestre - 2).

Permissão ao mestre na hora de entrar, não sair da roda, sem vir ao pé do berimbau (Mestre - 2).

O sociólogo Roger Bastide (2001) apresenta um estudo sobre o Candomblé na Bahia, que entre tantas análises, assevera a importância de uma confluência de forças, a fim de propiciar um ambiente favorável para a realização do ritual, as palmas, os cantos e o toque do atabaque são elementos capitais durante as cerimônias observadas pelo autor. Neste sentido, Mestres e professores de capoeira facultam em suas falas outras possibilidades de inserção na roda, para além do jogo propriamente dito.

Essa vontade é contagiante, fica curioso se saber quem é, e depois fica com vontade de ir lá participar, eu particularmente gosto muito de tocar berimbau, e essa é a minha maior forma de participação na roda de capoeira, pra contribuir com a roda mesmo (Mestre - 5).

Vou lá ver, pra saber se for possível, pra eu poder participar, hoje em dia com a minha idade eu não vou poder ajudar, mas ajudo nas palmas e no ritmo ou assistindo que é um modo de participar (Mestre - 5).

Mas tem como ir pra bater palma, cantar, conversar com os mestres, os alunos, os professores também, conhecer pessoas novas, às vezes pedir pra ficar perto e tocar também você está ali, o axé está bom, aí você toca um berimbau, aí toca e canta (Mestre - 5).

Dentro do ritual da capoeira existem alguns mecanismos que franqueiam a participação na roda, porém o ritmo parece ser peça fundamental para o bom andamento da cerimônia. Essa musicalidade protagonizada pelo berimbau além de conduzir o capoeirista ao rito é responsável pela harmonia física e espiritual dos capoeiristas. Continuemos na narrativa:

Essa coisa do berimbau leva a gente a imaginar. O que me colocou na capoeira foi escutar o berimbau lá no fundo do quintal do Mestre Paraná.Eu fui até lá e não parei mais (Mestre - 10).

Então a música ela nos leva a acreditar que a terra vibra, que na terra há uma movimentação, a música é a língua dos Deuses, e a música da capoeira ela te chama, ela 
te dá uma emanação tão grande no seu corpo e que você consegue conciliar o seu corpo com a alma (Mestre - 10).

Para Muniz Sodré (1998) o rito e seu contexto mítico são marcados por forças e poderes contrastantes, uma atmosfera emocional impregnada de tensão, alegria, tristeza, angústia, excitação, entre outros sentimentos experimentados e revisitados durante os ritos. O filósofo Ernest Cassirer (1972) empreende uma leitura do mito mostrando sua abrangência e relevância no mundo contemporâneo: "o verdadeiro substrato do mito não é de pensamento, mas de sentimento. Sua coerência depende muito mais de unidades de sentimentos que de regras lógicas" (p. 135). Notemos esses traços em nossos atores:

Eu sinto que já me perdi ali... jáme desviou do meu caminho. Rapaz, o coração acelera, eu tenho que ir lá ver o que é? Quemé? (Mestre - 3)

A música da capoeira ela te chama, ela te dá uma imanação tão grande no seu corpo (Mestre - 3).

Meu batimento cardíaco vai acima do limite quando escuto uma roda de capoeira, se tiver os instrumentos tocando, berimbau, atabaque, pandeiro, o meu batimento vai além do limite (Mestre -3 ).

Eu acho que a gente sente o que todas as pessoas sentem, vem uma coisa que é quase indescritível, acho que é a paixão, a capoeira eu acho, ela tem essa força, então a gente tem que parar pra olhar, cantar e participar (Mestre - 3).

É na roda de capoeira, com todos seus elementos simbólicos que a constituem como rito, que esses sentimentos afloram, tornando vívidas as pulsões emocionais que arrebatam os sujeitos, provocando uma eficaz adesão. Experimentadas em cada ritual, significando de uma maneira profunda os sentimentos de pertencimento dentro do grupo. Com Sodré (1998) podemos perceber como os ritmos africanos podem transmitir uma experiência mítica para o sujeito, que se vê envolto emocionalmente, essa adesão é sinal de um processo vivo de aprendizagem, que aderem e significam os sujeitos.

Quando se ouve o berimbau na primeira vez ele não sai do nosso corpo, então ao ver uma roda é impossível eu não parar na roda, por mais que tenha pessoas que você não goste, é impossível (Mestre - 8).

É a energia que eu recebo, é contagiante essa coisa (Mestre - 8).

Se tem muito daquela coisa da energia (Mestre - 8).

Vai lá chega perto, fica com vontade de se envolver de participar (Mestre-5). 


\begin{abstract}
Depois que você é envolvido pela capoeira, você quer contribuir com toda roda de capoeira que você vê, acho que você quer ir lá ver, quer contribuir, quer pôr a sua energia, é um ritual de troca (Mestre - 5).
\end{abstract}

Revisitando Lévi-Strauss (1989) podemos entender o rito também como uma fonte recíproca de energia, pois o sujeito contribui para sua manutenção, recebendo em troca a vitalidade. $\mathrm{O}$ rito é um retorno às origens míticas, que possibilita readquirir forças presentes nas raízes, nos momentos emblemáticos, de criação e superação. Muitas cantigas de capoeira remetem ao tempo da escravidão, com todos os percalços e superações que marcaram o povo africano no Brasil. Na fala dos sujeitos essa memória discursiva emerge: "quando eu chego na roda eu ... estou ali, me sinto um escravo, quando vou jogar". Essetempo imemorial, assim como as histórias dos grandes mestres são revisitados nas cantigas, contos e causos presentes no imaginário da capoeira.

MirceaEliade (1996) enfatiza a recuperação ou repetição imaginária desse tempo mítico durante as cerimônias ritualísticas. Para Roger Caillois (1938) as alusões a esse tempo sagrado desempenham um papel importante, exaltando e codificando a crença, por conseguinte, sugerindo os princípios que irão garantir a eficácia do rito. Tais práticas oferecem um modelo exemplar que, entre outras coisas, sacraliza o homem. Logo, as cantigas e os causos cumprem o papel de revisitar mitos como Mestre Bimba, Mestre Pastinha e Besouro Mangangá, revivendo as suas ações heróicas, assim como as expiações que os levaram a ocupar um lugar sagrado no imaginário social da capoeira, provocando a adesão emocional dos seus praticantes.

Ainda segundo Caillois (1938, p.24), as narrativas populares são importantes para a manutenção dos mitos, afinal não há rito sem mito, "separado do rito o mito perde sua razão de ser". Rito e mito são indissociáveis, pois as figuras míticas são exaltadas e alimentadas pelo ritual, atribuindo ao mesmo uma lógica simbólica, distinta ao pensamento racional. Neste sentido vale voltarmos a Pierre Ansart (1978) que avaliza a completude entre mito e rito assegurando as práticas sociais e os sentidos nos grupos.

O êxtase inicial do primeiro contato com a capoeira parece ser revivido a cada vez que o capoeirista entra na roda, estabelecendo relações com seu batizado, seu começo e origem na caminhada. MichellMaffesoli (2005), sociólogo francês e um dos maiores estudiosos do imaginário social da atualidade, diria que esse êxtase faz parte do jogo da eterna criação, que garante, além da adesão, a continuidade da pulsão de vida no grupo, a energia vital. Vejamos como o discurso nos convida a esse sentimento:

A adrenalina sobe, a gente fica naquele negócio... Parece o começo, o nosso começo da vida na capoeira. É a primeira vez que vou jogar numa roda? Não, não é a primeira vez! Mas a gente sente aquela coisa subir o suor mesmo, o suor do corpo e sente aquela coisa. A novidade. O novo entendeu? $\mathrm{O}$ sangue ferve primeiro e o coração sempre bate mais forte, independente do estilo e de qual grupo, sempre me chama muito atenção e sempre vou lá pra dar uma olhadinha (Mestre - 8).

Pô, o corpo se arrepia cara, o coração aperta quando toca o berimbau, vou para jogar capoeira se o mestre deixar, pô não tem como passar num lugar e ouvir o som do berimbau e não chegar perto (Mestre -8 ). 
Analisando as expectativas, bem como toda incerteza presente no jogo da capoeira e retratada nos discursos, somos levados à categoria da ilinx, desenvolvida por Caillois (1990) no intento de classificar os jogos. É nela que reside a vertigem, o transe, e o afastamento temporário da realidade. O capoeirista pode vivenciar a ilinx não somente nos movimentos acrobáticos e floreios que desafiam a gravidade em saltos mortais, giros em diferentes eixos do corpo e inversões corporais, mas, sobretudo no turbilhão emocional provocado pelo rito. Esse êxtase reflete diretamente no corpo, o mistério, o segredo, a imponderabilidade e a emoção, parecem permear as expectativas dos atores sociais, deixando marcas notórias nos capoeiristas.

A roda de capoeira, sob o prisma do ritual, aparece como catalisadora dessas emoções que fazem aflorar nos sujeitos diferentes respostas. Há uma tensão, uma tênue fronteira entre a lógica racional e as emoções pertencentes ao universo mítico, que subjazem traços desse imaginário. Assim, do mesmo modo que o capoeirista se entrega ao chamado do berimbau, mantém a consciência do risco que pode significar essa sedução, explicitando a tensão entre esta magia e a racionalidade:

Tenho medo com o compromisso que tenho, porque o toque do berimbau. Ele pode te atrair e você pode ficar ali, e começa-se conversar, o assunto torna-se tão gostoso que, se você for dar conta do seu compromisso, você tende a perder o seu compromisso (Mestre - 1).

Bom, eu sinto emoção, tenho vontade de jogar, vontade de estar lá, às vezes está indo para algum compromisso, não pode sair da roda o compromisso (Mestre - 1).

Nessa relação com as emoções, nossos atores se veem ameaçados em não conseguirem escapar do ritual, talvez receosos em se perderem do caminho de volta, do fio imaginário entre o mundo mítico, pautado no Axé, no lúdico, no gozo, e o mundo "real", reinado por Cronus, senhor do tempo, da coerência e da obrigação.

Essa lógica racional pode nos remeter às regras contratuais, obrigatórias, presentes nos empregos formais que tanto afugentaram os ex-escravos e descendentes do mercado de trabalho protocolar. O compromisso emerge nas formações discursivas como o outro da rua, do festejo, do gozo, do rito. Recorrendo a uma perspectiva apontada por DaMatta (1997), pode ser a tensão entre o lúdico da rua e a segurança da casa, que segundo o autor simboliza o controle, o governo das relações sociais. Já o lócusdo capoeirista historicamente tem sido a rua, palco de aventuras e incertezas, assim como, das surpresas imponderáveis do risco, do perigo (MOREIRA, 2007).

A construção imaginária do compromisso pode nos enviar a casa, local de segurança, de proteção maternal, de abrigo; porém também de claustro, clausura e castigo (CHEVALIER; GHEERBRANT, 2003). Em nosso percurso, vimos como o malandro se afasta desse pacto com a formalidade, com o protocolo, também associado à obrigação de levar o pão de cada dia para o lar, voltar ao cotidiano, ao acordo assumido diante da família, esposa, filhos... Neste sentido o compromisso também pode indicar uma disciplina a ser 
tomada como um valor imprescindível para o corpo produtivo, utilitário, sobretudo, para o mercado formal.

Nessa relação, o tempo cronológico é destinado às coisas "sérias", "produtivas", que de acordo com Walter Benjamim (1996) cada vez mais ocupam um lugar de destaque na sociedade. $\mathrm{O}$ intenso ritmo de desenvolvimento produtivo provocado pela revolução industrial e notório nos dias atuais, contrasta com a lógica do rito, do gozo, da festa. Com o autor, podemos refletir sobre o descompasso entre o tempo imposto pelas relações sociais capitalistas e o tempo dedicado aos bens culturais. A tendência do primeiro é o da produtividade, da eficácia, da necessidade imediata, enquanto para o segundo está em jogo o lúdico, a irreverência, a contemplação. Vejamos esses valores tensionados:

Olha a capoeira me deu tudo, acredito que sem a capoeira eu não teria sido a pessoa que sou hoje, eu trabalhava no escritório, trancadoe tinha um bom salário, tinha uma boa vida, uma boa esposa uma boa mulhermas quando me deram oportunidade de dar aula de capoeira eu larguei tudo, abandonei, fui pra fora, viajei e estou muito satisfeito (Mestre - 4).

O sujeito se lança por inteiro na aventura de viver a capoeira, norteado pelo pulso da vida e não pelo relógio de pulso, seguindo os impulsos do lúdico, do prazer, dos anseios, enfim das emoções circulantes no ritual da capoeira.

No entendimento de Muniz Sodré (1998), os ritos de matrizes africanas são responsáveis pela conexão do sujeito ao mundo invisível, sagrado. Acarretando também uma inteligibilidade da vida, capaz de remeter quem escuta, ao sentimento, à emoção, ao divino. Ainda para o autor, os ritmos africanos são carreadores para um tempo ancestral, um tempo que singulariza o grupo em torno de práticas e saberes coletivos, como mitos de origem, códigos de pertencimento e símbolos sagrados, que além de atribuir sentidos, são responsáveis pela coesão e pertencimento coletivo conforme viemos discutindo ao longo da pesquisa.

\section{CONSIDERAÇÕES FINAIS: ENCERRANDO A RODA}

Ao analisarmos os discursos dos mestres de capoeira que fizeram parte dessa pesquisa, desvela-se um universo simbólico que alude à própria historicidade da modalidade no Brasil. No ritual da capoeira o berimbau emerge significativamente como catalizador das energias circulantes na roda e mobilizador dos sujeitos ao rito, passaporte sagrado que conduz o capoeirista à roda. Com sua melodia dolente o berimbau aparece como elo entre o Orune o Aiê (Céu e Terra), transportando quem escuta a um mundo imemorial, talvez a Aruanda morada mítica dos Deuses africanos. Os descumprimentos dos preceitos podem desarmonizar a roda causando tensões e conflitos, notórios pra os capoeiristas envolvidos de corpo inteiro no ritual da capoeira. A falta do Axé pode ser um sinal aparente de que algo vai mal e pode resultar em brigas e confusões na roda. 
A forma de entregar-se aparece, nessa pesquisa, como uma imperiosa condição para "ser capoeirista de verdade", transcendendo os limites físicos do jogo, não se limitando a participação no ritual a performance na roda, mas a intensidade da entrega, determinante para a pulsão vital, alimentadora dos sujeitos envolvidos. Essa energia parece assolar o capoeirista, lançando-o de encontro ao rito, numa espécie de transe também conhecido como Axé. A energia desvelada na fala dos sujeitos se consubstancia no Axé como sinal de positividade e harmonia nas rodas de capoeira.

Há também indícios de um temor em se perder nos sinuosos caminhos do Axé e não voltar ao linear reino de Cronus. O primeiro encontra em seu ritual o lúdico, a festa e a contemplação como contributos de uma pulsão de vida; enquanto no segundo está o compromisso, comandado pela formalidade e rigidez, norteado pelo relógio de pulso.

O ritual da capoeira, para os mestres investigados, parece constituir um sentido de religiosidade entre os capoeiristas remetendo, talvez, às confrarias e irmandades, que historicamente resistiram às intempéries da escravidão. Essa crença no divino pode ser capaz de estabelecer uma ligação profunda nos atuais grupos de capoeira, apelando para uma construção imaginária circundada, em uma aura espiritual que perpassa a saga vivida pelo povo africano no Brasil, consolidando um pertencimento a totalidade do grupo.

Neste caminho, torna-se inequívoca, dentro do grupo pesquisado, uma relação entre os rituais religiosos de matrizes negras como o candomblé e umbanda, e a capoeira. Em ambos existem o sentido familiar, o transe, o Axé, a mandinga e a condução para um mundo mítico imemorial, uma ponte entre o Orun e o Aiê, um passaporte para o sagrado que parece constituir a rede imaginaria que amalgama capoeira e capoeiristas até os dias atuais.

\section{REFERÊNCIAS}

ANSART, P. Ideologias, conflitos e poder. Zahar, 1978.

BASTIDE, R. O Candomblé da Bahia: rito Nagô, São Paulo: Companhia das letras, 2001. BENJAMIM, W. Obras escolhidas: Magia e técnica, arte e política. São Paulo: Brasiliense, 1996.

BIANCARDI, E. Raízes musicais da Bahia. Salvador: Omar G, 2000.

BOLA SETE, M. A capoeira angola na Bahia. $2^{\text {a }}$ ed. Rio de Janeiro: Pallas, 1997.

BOURDIEU, P. O poder simbólico. 7a.ed. Rio de Janeiro: Bertrand Brasil, 2004.

CAILLOIS, R. Le mytheetl'homme. Paris: Gallimard, 1938.

.Os jogos e os homens: a mascara e a vertigem. Lisboa, Cotovia, 1990.

CASCUDO, L. da C. Dicionário do folclore brasileiro. 11a Ed. São Paulo: Global, 2001.

CASSIRER, E. Linguagem e mito. Tradução de J. Guinsburg e Miriam Schnaiderman.São

Paulo: Perspectiva, 1972.

CHEVALIER, J.; GHEERBRANT, A. Dicionário de símbolos: mitos, sonhos, costumes, gestos, formas, figuras, cores, números. 18a Ed. Rio de Janeiro: José Olympio, 2003.

COLUMÁ, J. F.; CHAVES, S. F. O sagrado no jogo de capoeira. Textos escolhidos de cultura

e arte populares, Rio de Janeiro, v.10, n.1, p. 169-182, mai. 2013. 
DAMATTA, R.Carnavais malandros e heróis: para uma sociologia do dilema brasileiro. $6^{\mathrm{a}}$ ed. Rio de Janeiro: Rocco, 1997.

DE LOS RIOS, A. M. F. O Rio de Janeiro Imperial: Rio de Janeiro: Topbooks, 2000.

EDMUNDO, L. O Rio de Janeiro do meu tempo. Rio de Janeiro: Conquista, 1957.

ELIADE, M. O sagrado e o profano a essência das religiões. São Paulo: Martins Fontes, 1996.

GRIMM, I. Contos de Fadas. $4^{\mathrm{a}}$ ed. São Paulo: Iluminuras, 2002.

JOÃO GRANDE. Capoeira Angola Center of Mestre. Disponível em: < www.joaogrande. org/mestre.htm > . Acesso em out. 2011.

LÉVI-STRAUSS, C. Antropologia Estrutural. Rio de Janeiro: Tempo Brasileiro, 1989.

MAFFESOLI, M.A Sombra de Dionísio: Contribuição a uma sociologia da orgia. $2^{\mathrm{a}} \mathrm{Ed}$. São Paulo: Zouk, 2005.

MANDINGA em Manhattan. Cultura marcas, 2006.

MOREIRA, J. F. F. Da navalha ao berimbau: a malandragem no imaginário da capoeira carioca. (Tese de doutorado). Rio de Janeiro: PPGEF/UGF, 2011.

MOREIRA, J. F. F. Arte, Magia e Malandragem: o imaginário cantado nas rodas de capoeira. Dissertação de mestrado. Rio de Janeiro: PPGEF/UGF, 2007.

OGBEBARA, A. Igbadú: a cabaça da existência: mitos nagôs revelados. Rio de Jjaneiro: Pallas, 1998.

ORLANDI, E. P. Discurso e Texto: Formulação e circulação dos sentidos Campinas, SP, Pontes 2001.

PIRES, A. L. C. S.Culturas circulares: a formação histórica da capoeira contemporânea no Rio de Janeiro. Curitiba: Editora Progressiva, 2010. Salvador: Fundação Jair Moura, 2010.

REGO, W. Capoeira angola um ensaio sócio-etnográfico. $1^{\mathrm{a}}$ ed. Salvador, BA: Itapuã coleção baiana, 1968.

SACHS, C. The History of musical instruments. New York, 1940.

SHAFFER, K. O berimbau de barriga e seus toques. Monografias folclóricas -2 , Instituto nacional de folclore, 1977.

SODRÉ, M. Samba o dono do corpo. $2^{\text {a }}$ Ed. Rio de Janeiro: Mauad, 1998.

SOARES, A. J. G. Futebol, malandragem e identidade. Vitória: SPDC/UFES, 1994.

SOARES, C. E. L. A negregada instituição: os capoeiras no Rio de Janeiro. Rio de Janeiro: Secretaria Municipal de Cultura, 1994.

Recebido em: outubro/2016 Aprovado em: fevereiro/2017 